\title{
PENERAPAN MODEL STAD-PROBLEM SOLVING UNTUK MENINGKATKAN PROSES DAN HASIL BELAJAR SISWA
}

\author{
Erna Yayuk \\ Universitas Negeri Malang, Jalan Semarang 5 Malang 65145 \\ E-mail: er_2y@yahoo.co.id
}

\begin{abstract}
The purpose of this research is to apply STAD-Problem Solving model to improve student's learning process and student achievement mathematics. This type of research is classroom action research (CAR). The characteristic of classroom action research (CAR) is a cyclic research. Each cycle is completed with cooperative learning strategy model STADProblem Solving, with the subject matter is integers (mathematics). The subject of this research is the fourth grader of SD Muhammadiyah 8 Dau Malang. The result of this research is cooperative learning model STAD-Problem Solving can improve process quality and student achievement.
\end{abstract}

Keywords: STAD, problem solving, quality process, learning achievement, mathematics

\begin{abstract}
Abstrak: Tujuan penelitian ini adalah menerapkan model STAD-Problem Solving untuk meningkatkan proses dan hasil belajar matematika siswa. Jenis penelitian ini adalah Penelitian Tindakan Kelas (PTK). Ciri penelitian Penelitian Tindakan Kelas (PTK) adalah penelitian yang bersiklus. Setiap siklus dilakukan pembelajaran dengan strategi pembelajaran kooperatif model STAD-Problem Solving dengan materi pelajaran Bilangan Bulat. Subyek penelitian adalah siswa Kelas IV SD Muhammadiyah 8 Dau Malang. Hasil penelitian ini adalah pembelajaran kooperatif model STAD-Problem Solving dapat meningkatkan kualitas proses dan hasil belajar siswa.
\end{abstract}

Kata kunci: STAD, problem solving, kualitas proses, hasil belajar, matematika

Guru memiliki peran yang sangat penting dalam menentukan kuantitas dan kualitas pengajaran yang dilaksanakannya. Oleh sebab itu, guru harus memikirkan dan membuat perencanaan secara seksama dalam meningkatkan kesempatan belajar bagi siswanya dan memperbaiki kualitas mengajarnya. Untuk memenuhi hal tersebut di atas guru dituntut mampu mengelola proses belajar-mengajar yang memberikan rangsangan kepada siswa sehingga ia mau belajar karena siswalah subjek utama dalam belajar. Dalam menciptakan kondisi belajar-mengajar efektif harus ada partisipasi aktif dari siswa, apalagi dalam pembelajaran matematika.

Pembelajaran di sekolah tersebut pada umumnya cenderung berorientasi pada metode ceramah. Ciri-ciri yang nampak pada pembelajaran tersebut adalah klasikal, berpusat pada guru dan kurang interaktif. Guru mengajar pada seluruh siswa di kelas pada saat yang bersamaan. Semua keputusan tentang topik-topik yang akan dipelajari dan susunan penyajian serta jumlah waktu yang disediakan untuk setiap topik diatur sepenuhnya oleh guru. Interaksi antara guru dengan siswa atau antara siswa dengan siswa di kelas sangat rendah. Dalam bentuk pembelajaran semacam ini, siswa hanya berperan sebagai penerima informasi secara pasif karena hanya mendengarkan dan mencatat informasi dari guru saja.

Implikasi dari pembelajaran matematika secara ceramah di atas menyebabkan pembelajaran yang terjadi kurang bermakna. Siswa lebih banyak menghafal daripada mengkontruksi pengetahuannya sendiri. Beberapa fakta tentang rendahnya kualitas proses pembelajaran tersebut adalah: (1) dalam pembelajaran siswa cenderung pasif, jarang mengajukan pertanyaan, jika menemui kesulitan mereka takut bertanya, jika ada pertanyaan guru, siswa cenderung diam atau tidak bisa menjawab; (2) adanya keluhan guru yang mengajar mata pelajaran matematika, bahwa banyak siswa yang sudah Kelas IV tetapi 
tidak menguasai konsep matematika; dan (3) siswa memiliki ketuntasan belajar matematika berkisar $50 \%$ s.d. $60 \%$. Interaksi antara guru dan siswa atau antara siswa dan siswa di kelas sangat rendah. Selain itu pada saat guru memberi kesempatan kepada siswa untuk bertanya, siswa tidak mengajukan pertanyaan mengenai penjelasan materi yang disampaikan oleh guru. Namun ketika siswa diberi tugas berupa soal, sebagian besar siswa masih terlihat bingung dan kesulitan dalam memecahkan masalah.

Hal ini menunjukkan bahwa sifat pasif siswa dalam proses pembelajaran akan mengakibatkan siswa mengalami kesulitan untuk melanjutkan kegiatan pembelajaran. Sebagian besar siswa masih mengalami kesulitan dalam menyelesaikan soal-soal yang tidak dapat dipecahkan oleh suatu prosedur rutin terutama pada pokok bahasan melakukan operasi hitung bilangan bulat dalam pemecahan masalah (problem solving). Hal ini dikarenakan guru jarang memberikan latihan soal pemecahan masalah matematika, siswa merasa takut dan malu bertanya jika mereka belum mengerti. Pada dasarnya kesulitan siswa dapat diatasi jika mereka berani bertanya sebelum guru melanjutkan penjelasan materi berikutnya. Sehinggga kesulitan materi yang dialami siswa tidak berkelanjutan. Guru dalam hal ini dituntut dapat mengadakan variasi pembelajaran baik dalam penggunaan strategi pembelajaran maupun pengunaan model pembelajaran. Hal ini ditujukan agar siswa tidak mengalami kejenuhan dalam proses pembelajaran di kelas dan diharapkan dapat meningkatkan motivasi belajar siswa.

Akibat pembelajaran matematika seperti di atas, tingkat pemahaman siswa terhadap matematika rendah, dan matematika dirasakan sebagai pelajaran sulit bagi sebagian besar siswa. Dalam belajar matematika banyak sekali tuntutan yang harus dipenuhi baik oleh guru maupun siswa dan seringkali tuntutan ini tidak dapat diatasi (Stieff \& Wilensky, 2003). Misalnya, agar matematika dapat dipahami dengan baik, siswa harus menguasai tiga aspek matematika, yaitu: (1) mengetahui apa saja materi matematika tersebut dan bagaimana kaitannya dengan fenomena alam; (2) memahami konsep pada mata pelajaran Matematika serta memahami kaitannya dengan fenomena alam yang sesuai; dan (3) terampil dalam memecahkan permasalahan berkaitan dengan materi mata pelajaran matematika (Jonhston, 2000). Selain itu, karena kekomplekan struktur keilmuan dari matematika sendiri yang menyebabkan matematika sulit lingkungan atau atmosfer belajar tampaknya juga kurang kondusif untuk terjadinya pemahaman konsep yang optimal (Gabel, 1999).

Salah satu cara untuk memahami bagaimana siswa belajar adalah melalui filosofi konstruktivisme yang diyakini para pakar pendidikan saat ini. Konstruktivisme memandang belajar sebagai sebuah proses sosial, bersifat dinamis dimana siswa mengkostruksi secara aktif makna dari pengalaman-pengalaman mereka dikaitkan dengan pemahaman awal dalam kemasan setting social (Driver, 1994). Beberapa contoh strategi pembelajaran konstruktivis adalah pembelajaraan kooperatif, learning cycle, dan generative learning. Untuk meningkatkan kualitas proses dan hasil pembelajaran matematika perlu dilakukan berbagai cara, salah satu di antaranya adalah dengan menerapkan model pembelajaran yang tepat. Untuk menentukan model pembelajaran tersebut tidaklah mudah, harus melalui penelitian dan uji coba berulang-ulang.

Salah satu pendekatan atau strategi pembelajaran berbasis konstruktivis yaitu pembelajaran kooperatif model STAD (Student Teams Achievement Divisions) yang dikembangkan oleh Slavin pada tahun 1978 di John Hopkins University. Hasil penelitian menunjukkan bahwa model pembelajaran STAD dapat meningkatkan hasil belajar siswa (Supriyatiningsih, 2008). Solikhati (2003) menyatakan bahwa penerapan STAD mempengaruhi: (1) hasil belajar siswa meningkat; (2) pembelajaran tidak membosankan dan siswa merasa termotivasi untuk belajar; dan (3) setiap siswa terlibat aktif. Polya (1973) menyatakan guru harus mengerahkan seluruh kemampuannya untuk membangun kemampuan siswa dalam menyelesaikan masalah. Hal ini penting karena siswa setiap harinya selalu dihadapkan pada suatu masalah. Problem solving merupakan suatu pendekatan pembelajaran yang sifatnya teoritis atau konseptual untuk melatihkan siswa memecahkan masalah-masalah dengan menggunakan berbagai strategi dan langkah pemecahan masalah yang ada (Billstein, 2010). Sumarno (2011) berdasarkan 
hasil penelitiannya menunjukkan bahwa berlatih dalam problem solving dapat meningkatkan kualitas proses pembelajaran.

\section{METODE}

Penelitian ini dilaksakan dengan pendekatan penelitian tindakan kelas (PTK), karena penelitian dilakukan untuk memecahkan masalah pembelajaran di kelas. Penelitian ini juga termasuk penelitian deskriptif, sebab menggambarkan bagaimana suatu teknik pembelajaran diterapkan dan bagaimana hasil yang diinginkan dapat dicapai. PTK adalah proses investigasi terkendali untuk menemukan dan memecahkan masalah pembelajaran di kelas, proses pemecahan masalah tersebut dilakukan secara bersiklus, dengan tujuan untuk meningkatkan kualitas proses dan hasil pembelajaran di kelas tertentu. Ciri-ciri utama PTK adalah: (1) masalahnya berasal dari latar/kelas tempat penelitian dilakukan; (2) proses pemecahan masalah tersebut dilakukan secara bersiklus; dan (3) tujuannya untuk memecahkan masalah pembelajaran di kelas, atau meningkatkan kualitas pembelajaran di kelas (Akbar, 2009; Gunawan, 2016a).

Sesuai dengan jenis penelitian yang dipilih, yaitu penelitian tindakan kelas, maka penelitian ini menggunakan model penelitian tindakan dari Kemmis dan Taggart, yaitu berbentuk spiral dari siklus satu ke siklus berikutnya. Setiap siklus meliputi planning, action, observation, dan reflection (Akbar, 2009). Langkah pada siklus berikutnya adalah perencanaan yang sudah direvisi, tindakan, pengamatan, dan refleksi. Sebelum masuk pada siklus 1 dilakukan tindakan pendahuluan yang berupa identifikasi permasalahan. Penelitian tindakan ini menggunakan bentuk penelitian kolaboratif. Tujuan utama dari penelitian tindakan ini adalah untuk meningkatkan kualitas pembelajaran di kelas dimana guru secara penuh terlibat dalam penelitian mulai dari perencanaan, tindakan, pengamatan, dan refleksi.

Peneliti bekerjasama dengan guru kelas, kehadiran peneliti sebagai pengajar dan dibantu dua orang observer, yaitu satu orang dosen dari PGSD UMM dan satu orang guru kelas di SD
Muhammadiyah 8 Dau Malang. Penelitian dengan cara ini diharapkan didapatkan data yang seobjektif mungkin demi kevalidan data yang diperlukan. Data yang dikumpulkan dalam penelitian ini meliputi: (1) data tentang kegiatan guru dalam proses pembelajaran dengan model STAD-Problem Solving; (2) data tentang kegiatan siswa selama mengikuti kegiatan proses pembelajaran dengan model STAD-Problem Solving; dan (3) data hasil belajar siswa tentang kemampuan memecahkan masalah matematika.

Instrumen yang digunakan dalam penelitian ini adalah: (1) instrumen-instrumen yang berkaitan dengan proses pembelajaran. Instrumen-intrumen yang termasuk kelompok ini berupa jurnal guru (field notes), lembar observasi untuk mengamati jalannya proses pembelajaran, dan pedoman wawancara tentang persepsi siswa terhadap proses pembelajaran yang telah diikutinya, jurnal guru (field notes) adalah berupa catatan-catatan dari hasil pengamatan guru tentang kejadian-kejadian selama proses pembelajaran berlangsung; dan (2) instrumen-instrumen yang berkaitan dengan hasil belajar siswa. Instrumen-instrumen yang termasuk kelompok ini adalah soal pre test untuk mengetahui hasil belajar awal sebagai dasar pengelompokan siswa, soal post test untuk mengetahui hasil belajar akhir pada masing-masing siklus.

Teknik analisis data yang digunakan dalam penelitian tindakan kelas ini meliputi analisis kualitatif dan kuantitatif. Analisis kualitatif dilakukan untuk mengetahui kualitas proses pembelajaran kooperatif model STAD-Problem Solving dari data observasi keterampilan berkolaborasi selama proses pembelajaran berlangsung, jurnal guru, dan hasil wawancara siswa terhadap proses pembelajaran yang diikutinya. Hasil wawancara siswa dianalisis kemudian hasilnya diintegrasikan dengan hasil analisis data dari observasi langsung dari jurnal guru dan blangko observasi. Analisis kuantitatif dilakukan untuk mengetahui hasil belajar siswa dengan melihat rata-rata skor, persentase nilai yang berkualifikasi baik, dan persentase kelulusan siswa terhadap kemampuan ranah kognitif suatu materi pelajaran yang meliputi aspek pengetahuan, pemahaman konsep, dan aplikasi. 
HASIL

\section{Siklus I}

\section{Aktivitas Guru dan Siswa}

Hasilpengamatanolehkeduaobserverterhadap aktivitas guru dalam kegiatan pembelajaran pada siklus I di kelas menunjukkan hasil yang sangat baik. Kegiatan keterlaksanaan pembelajaran yang telah dilakukan oleh guru dengan pembelajaran kooperatif model STAD-Problem Solving dalam bentuk persentase ditunjukkan pada Tabel 1. Tabel 2 menampilkan hasil aktivitas yang dilakukan oleh kedua observer pada pembelajaran model STADProblem Solving dalam bentuk persentase.

Berdasarkan paparan hasil observasi ratarata dari dari kedua observer pada Tabel 2 dapat disimpulkan bahwa pada siklus I, keaktivan siswa berada pada kategori cukup, kreativitas berada pada kategori kurang, rasa senang siswa berada pada kategori kurang, dan interaksi siswa pada proses pembelajaran berada pada kategori cukup. Analisis data demikian tidak memenuhi kategori baik atau sangat baik sehingga kategori tersebut akan dijadikan bahan pertimbangan untuk memperbaiki tindakan berikutnya.

\section{Hasil Belajar Siswa}

Analisis data mengenai hasil belajar siswa dilakukan dengan menghitung jumlah siswa yang telah tuntas belajar dari kuis (post tes) dengan materi yang telah diberikan selama proses pembelajaran yaitu mengurutkan dan menjumlahkan bilangan bulat. Berdasarkan ketuntasan belajar di SD Muhammadiyah 8 Dau, siswa dikatakan tuntas secara klasikal apabila siswa yang mendapat skor $\geq 61$ paling sedikit $75 \%$. Berdasarkan nilai yang diperoleh dari hasil tes diketahui bahwa ada 20 siswa yang mencapai KKM dan ada 8 siswa yang masih belum mencapai Kriteria Ketuntasan Minimal (KKM) dari 28 siswa, sehingga persentase ketuntasan klasikal 71,43\% dan sisanya $28,57 \%$ belum tuntas. Presentase tersebut belum memenuhi ketuntasan belajar secara klasikal sebesar 75\%. Karena hasil analisis yang diperoleh belum mencapai kategori tersebut, maka penelitian akan dilanjutkan ke siklus II.

\section{Siklus II}

\section{Aktivitas Guru dan Siswa}

Dari hasil pengamatan kedua observer terhadap aktivitas guru dalam kegiatan pembe-

Tabel 1 Hasil Observasi Aktivitas Guru oleh Kedua Observer pada Siklus I

\begin{tabular}{|c|c|c|c|}
\hline & & Observer I & Observer II \\
\hline Pertemuan I & $\begin{array}{l}\text { Skor Perolehan } \\
\text { Skor maksimal } \\
\text { Persentase } \\
\text { Kriteria } \\
\end{array}$ & $\begin{array}{c}42 \\
50 \\
84 \% \\
\text { Baik } \\
\end{array}$ & $\begin{array}{c}39 \\
50 \\
78 \% \\
\text { Cukup } \\
\end{array}$ \\
\hline Pertemuan II & $\begin{array}{l}\text { Skor perolehan } \\
\text { Skor maksimal } \\
\text { Persentase } \\
\text { Kriteria }\end{array}$ & $\begin{array}{c}46 \\
50 \\
92 \% \\
\text { Sangat baik }\end{array}$ & $\begin{array}{c}45 \\
50 \\
90 \% \\
\text { Sangat baik }\end{array}$ \\
\hline Pertemuan III-IV & $\begin{array}{l}\text { Skor perolehan } \\
\text { Skor maksimal } \\
\text { Persentase } \\
\text { Kriteria }\end{array}$ & $\begin{array}{c}48 \\
50 \\
96 \% \\
\text { Sangat baik }\end{array}$ & $\begin{array}{c}48 \\
50 \\
96 \% \\
\text { Sangat baik }\end{array}$ \\
\hline
\end{tabular}

Tabel 2 Hasil Observasi Aktivitas Siswa oleh Kedua Observer pada Siklus I

\begin{tabular}{|c|c|c|c|c|c|}
\hline & & $\begin{array}{c}\text { Aktivitas } \\
\text { Belajar }\end{array}$ & Kreativitas & Rasa senang & Interaksi \\
\hline \multirow[t]{3}{*}{ Pertemuan I } & Rata-rata skor perolehan & 2,80 & 1,93 & 2,95 & 2,17 \\
\hline & $\begin{array}{l}\text { Skor maksimal } \\
\text { Persentase }\end{array}$ & $70 \%$ & $48.25 \%$ & $73.75 \%$ & $54.25 \%$ \\
\hline & Kriteria & Cukup & Sangat kurang & Cukup & Sangat kurang \\
\hline \multirow[t]{3}{*}{ Pertemuan II } & Rata-rata skor perolehan & 3,00 & 2,30 & 2,23 & 3,40 \\
\hline & $\begin{array}{l}\text { Skor maksimal } \\
\text { Persentase }\end{array}$ & $75 \%$ & $57.50 \%$ & $55.75 \%$ & $85^{4} \%$ \\
\hline & Kriteria & Cukup & Sangat kurang & Sangat kurang & Baik \\
\hline \multirow[t]{3}{*}{ Pertemuan III-IV } & Rata-rata skor perolehan & 3,20 & 2,95 & 3,08 & 3,47 \\
\hline & $\begin{array}{l}\text { Skor maksimal } \\
\text { Persentase }\end{array}$ & $\begin{array}{c}4 \\
80 \%\end{array}$ & $73.75 \%$ & $\begin{array}{c}4 \\
77 \%\end{array}$ & $86.75 \%$ \\
\hline & Kriteria & Baik & Cukup & Cukup & Baik \\
\hline
\end{tabular}


lajaran pada siklus II di kelas menunjukkan hasil yang sangat baik. Kegiatan keterlaksanaan pembelajaran yang telah dilakukan oleh guru dengan pembelajaran model STAD-Problem Solving dalam bentuk persentase ditunjukkan pada Tabel 3.

Berdasarkan hasil dari kedua observer terhadap penilaian aktivitas guru selama proses pembelajaran Siklus II berlangsung diperoleh ratarata sebesar 93,5\%. Hal ini berarti aktivitas guru berada pada kategori sangat baik. Pada Siklus II ini keaktivan siswa mencai skor rata-rata 3,51 atau mencapai $87,75 \%$ dari skor maksimal yang diharapkan dengan kategori baik. Kreativitas siswa mencapai skor rata-rata 3,22 atau mencapai $83,5 \%$ dari skor maksimal yang diharapkan dengan kategori baik. Rasa senang siswa mencapai skor rata-rata 3,33 atau mencapai $83,25 \%$ dari skor maksimal yang diharapkan dengan kategori baik. Kualitas interaksi siswa mencapai skor rata-rata 3,63 atau mencapai $90,75 \%$ dari skor maksimal yang diharapkan dengan kategori sangat baik.
Tabel 4 menampilkan hasil aktivitas yang dilakukan oleh kedua observer pada pembelajaran model STAD-Problem Solving dalam bentuk persentase. Berdasarkan data hasil pengamatan yang dilakukan oleh kedua observer di atas terhadap keaktivan, kreativitas, rasa senang, dan interaksi siswa dalam proses pembelajaran terdapat peningkatan dari siklus I ke siklus II. Adapun peningkatan tersebut dapat dilihat pada Tabel 5.

\section{Hasil Belajar Siswa}

Analisis data mengenai hasil belajar siswa dilakukan dengan menghitung jumlah siswa yang telah tuntas belajar dari kuis(Post tes) dengan materi yang telah diberikan selama proses pembelajaran yaitu mengurangkan bilangan bulat. Berdasarkan ketuntasan belajar di SD Muhammadiyah 8 Dau, siswa dikatakan tuntas secara klasikal apabila siswa yang mendapat skor $\geq 61$ paling sedikit $75 \%$. Berdasarkan nilai yang diperoleh dari hasil tes diketahui bahwa ada 24 siswa yang mencapai KKM dan ada 4 siswa yang masih belum mencapai

Tabel 3 Hasil Observasi Aktivitas Guru oleh Kedua Observer pada Siklus II

\begin{tabular}{llcc}
\hline & & Observer & Observer II \\
\hline Pertemuan VI & Skor perolehan & 46 & 47 \\
& Skor maksimal & 50 & 50 \\
& Persentase & $92 \%$ & $94 \%$ \\
& Kriteria & Sangat Baik & Sangat Baik \\
\hline Pertemuan VII & Skor perolehan & 47 & 47 \\
& Skor maksimal & 50 & 50 \\
& Persentase & $94 \%$ & $94 \%$ \\
& Kriteria & Sangat Baik & Sangat Baik \\
\hline
\end{tabular}

Tabel 4 Hasil Observasi Aktivitas Siswa oleh Kedua Observer (Siklus II)

\begin{tabular}{|c|c|c|c|c|c|}
\hline & & $\begin{array}{c}\text { Aktivitas } \\
\text { Belajar }\end{array}$ & Kreativitas & $\begin{array}{c}\text { Rasa } \\
\text { senang }\end{array}$ & Interaksi \\
\hline \multirow[t]{4}{*}{ Pertemuan VI } & Rata-rata skor perolehan & 3,51 & 3,25 & $3,53^{\circ}$ & 3,63 \\
\hline & Skor maksimal & 4 & 4 & 4 & 4 \\
\hline & Persentase & $87,75 \%$ & $81,25 \%$ & $88,25 \%$ & $90,75 \%$ \\
\hline & Kriteria & Baik & Baik & Baik & Sangat Baik \\
\hline \multirow{4}{*}{$\begin{array}{l}\text { Pertemuan } \\
\text { VII }\end{array}$} & Rata-rata skor perolehan & 3,51 & 3,43 & 3,13 & 3,63 \\
\hline & Skor maksimal & 4 & 4 & 4 & 4 \\
\hline & Persentase & $87,75 \%$ & $85,75 \%$ & $78,25 \%$ & $90,75 \%$ \\
\hline & Kriteria & Baik & Baik & Cukup & Sangat Baik \\
\hline
\end{tabular}

Tabel 5 Hasil Observasi Aktivitas Siswa Siklus I dan Siklus II

\begin{tabular}{lllcccc}
\hline \multicolumn{2}{l}{} & & $\begin{array}{c}\text { Aktivitas } \\
\text { Belajar }\end{array}$ & Kreativitas & $\begin{array}{c}\text { Rasa } \\
\text { senang }\end{array}$ & Interaksi \\
\hline \multirow{2}{*}{ Siklus } & Rata-rata skor perolehan & 3,0 & 2,39 & 2,75 & 3,01 \\
\cline { 2 - 6 } & Skor maksimal & 4 & 4 & 4 & 4 \\
\cline { 2 - 6 } & Persentase & $75 \%$ & $59,75 \%$ & $68,75 \%$ & $75,25 \%$ \\
\cline { 2 - 6 } & Kriteria & Cukup & Sangat kurang & Kurang & Cukup \\
\hline \multirow{2}{*}{ Siklus II } & Rata-rata skor perolehan & 3,51 & 3,22 & 3,33 & 3,63 \\
& Skor maksimal & 4 & 4 & 4 & 4 \\
& Sersentase & $87,75 \%$ & $83,5 \%$ & $83,25 \%$ & $90,75 \%$ \\
\cline { 2 - 6 } & Kriteria & Baik & Baik & Baik & Sangat Baik \\
\hline
\end{tabular}


Kriteria Ketuntasan Minimal (KKM) dari 28 siswa, sehingga persentase ketuntasan klasikal 85,71\% dan sisanya $14,29 \%$ belum tuntas. Presentase tersebut sudah memenuhi ketuntasan belajar secara klasikal sebesar $75 \%$.

\section{PEMBAHASAN}

Penelitian ini mengemas proses pembelajaran kooperatif model STAD-Problem Solving dikemas dalam bentuk diskusi kelompok untuk mencari dan memecahkan masalah, ternyata dapat menghasilkan proses pembelajaran yang berkualitas baik, walaupun ada beberapa hal yang belum optimal. Temuan ini didasarkan adanya hasil observasi selama proses pembelajaran berlangsung yang antara lain indikatornya dapat membuat siswa: (1) termotivasi dan senang untuk belajar; (2) mau dan mampu mengemukakan persoalan yang belum dikuasainya; (3) aktif berusaha memecahkan masalah baik dengan menganalisis sendiri maupun bertanya kepada temannya; (4) Kreatif memanipulasi alat peraga untuk menyelesaikan masalah matematika yang ada pada Lembar Kerja Siswa; (5) mampu bekerjasama dalam kelompok secara konstruktif walaupun belum berlangsung secara optimal; (6) mampu melakukan tutorial sebaya dari siswa yang lebih pandai kepada yang kurang pandai; dan (7) mampu menghasilkan hasil diskusi yang baik berupa laporan hasil diskusi yang umumnya mempunyai skor nilai yang relatif tinggi, walaupun dalam menjawab soal kuis masih ada yang salah.

Temuan tersebut sesuai dengan pendapat Hamalik (2001) yang menyatakan bahwa indikator proses pembelajaran yang berkulitas baik adalah yang mampu: (1) membuat siswa aktif belajar; (2) menciptakan situasi yang menyenangkan siswa dalam belajar; (3) memudahkan siswa menyerap materi pelajaran; (4) menumbuhkan kesadaran belajar mandiri siswa; (5) mendorong terjadinya tutorial sebaya; (6) menumbuhkan sikap siswa yang dapat menghargai pendapat orang lain; (7) memupuk kemampuan bekerjasama siswa; (8) menumbuhkan sikap teliti dan hati-hati pada diri siswa; (9) mendorong siswa untuk serius dalam belajar; (10) meningkatkan daya nalar/berpikir siswa; dan (11) membentuk kedisiplinan siswa. Pada awal pembelajaran, siswa dipersiapkan agar benar-benar siap untuk belajar. Hal ini mendukung pendapat Orton (1992) yang menyatakan bahwa siswa yang siap untuk belajar akan belajar lebih banyak daripada siswa yang tidak siap. Kegiatan menyiapkan siswa meliputi persiapan fisik dan persiapan mental. Persiapan fisik meliputi menyediakan semua sarana yang diperlukan berupa alat peraga, Lembar Kegiatan Siswa (LKS) dan membagi siswa dalam kelompokkelompok. Sedangkan persiapan mental meliputi kegiatan menyampaikan salam, bertanya kabar, menyampaikan tujuan, memotivasi siswa tentang pentingnya materi bilangan bulat.

Peran guru sangatlah penting di dalam proses pembelajaran. Dalam pembelajaran kooperatif model STAD-Problem Solving ini, guru memfungsikan dirinya sebagai fasilitator, mediator dan motivator. Oleh karena itu, tugas seorang guru pada pembelajaran ini adalah memandu, membimbing, dan membantu siswa jika dibutuhkan. Guru membimbing dan membantu siswa melalui pertanyaan-pertanyaan arahan yang nantinya akan dikembangkan sendiri oleh siswa. Hal ini sesuai dengan pendapat Vygotsky tentang Scaffolding bahwa pemberian sejumlah bantuan kepada siswa selama tahap-tahap awal pembelajaran, kemudian mengurangi bantuan dan memberikan kesempatan untuk mengambil alih tanggung jawab yang semakin besar setelah ia dapat melakukannya (Slavin,1994). Scaffolding merupakan bantuan yang diberikan kepada siswa untuk belajar dan memecahkan masalah. Kepala sekolah memiliki kewenangan untuk membina guru agar terus meningkatkan kualitas pembejarannya (Gunawan, 2016b).

Berdasarkan temuan penelitian ini, pembelajaran kooperatif model STAD-Problem Solving dapat meningkatkan kualitas proses pembelajaran siswa. Hal ini disebabkan karena dalam pembelajaran ini siswa berusaha menemukan konsep operasi hitung bilangan bulat melalui alat peraga, siswa mampu bekerja secara kelompok mengerjakan lembar kerja siswa serta menggunakan pengetahuannya untuk memecahkan masalah yang baru dalam konteks yang baru. Hal ini menyebabkan siswa menjadi lebih aktif, baik secara fisik maupun mental. Hal ini didukung pendapat Sardiman (2007) yang menyatakan bahwa aktivitas pembelajaran siswa akan meningkat ketika guru mampu mendorong siswa tersebut untuk berfikir dan be- 
raktivitas dalam hal menyelesaikan masalah sesuai perkembangan kognitifnya dan berdasarkan pengalaman yang dimilikinya. Senada dengan hal tersebut, Sumarno (2011) juga menemukan bahwa berlatih dalam problem solving dapat meningkatkan kualitas proses pembelajaran matematika.

Siklus I pertemuan pertama, masih ada beberapa siswa yang bekerja sendiri-sendiri dalam kelompoknya, siswa belum berani mengemukakan ide dan memberi tanggapan terhadap jawaban atau penampilan temanya. Hal ini disebabkan karena siswa belum terbiasa belajar secara kelompok dan berdiskusi dengan temannya serta sifat individual siswa masih melekat. Namun setelah dilakukan motivasi dan pemberian penghargaan berupa bintang prestasi pada siklus II, keaktifan siswa menjadi meningkat cukup tajam. Mereka berlomba-lomba untuk memperoleh bintang prestasi sebanyak-banyaknya. Penerapan pembelajaran model STAD-Problem Solving mampu meningkatkan rasa ingin tau mereka, sehingga keinginan siswa untuk belajar menjadi meningkat.

Perubahan pola pembelajaran yang berbeda dari biasanya dapat mem-pengaruhi aktivitas belajar siswa. Situasi tersebut tercermin pada awal kerjasama yang terjadi pada kelompok belajar. Aktivitas dan motivasi siswa terhadap pembelajaran kooperatif model STAD-Problem Solving sangat baik. Berdasarkan pengamatan ketika pembelajaran berlangsung, siswa tampak antusias dalam melakukan diskusi sesama anggota kelompok. Semua anggota kelompok terlibat pada waktu memanipulasi alat peraga. Mereka terlihat semangat lagi dan kegembiraan mereka ketika diskusi kelompok dibuat model permainan dengan kompetisi antar kelompok.

Pembelajaran yang dilakukan dalam Siklus I, hasil belajar siswa sudah cukup, akan tetapi keaktivan, kreativitas, rasa senang, dan interaksi siswa dalam proses pembelajaran masih kurang memuaskan, hal ini terjadi karena siswa belum terbiasa dan belum berpengalaman dengan pembelajaran kooperatif model STAD-Problem Solving, siswa masih enggan berkelompok dengan anggota kelompok yang bukan teman akrabnya, siswa terbiasa belajar individu sehingga masih ada beberapa siswa yang pintar tetapi tidak mau mengajari yang kurang mampu. Hal ini didukung pendapat Slavin (2008) bahwa anak pada masa sekolah dasar, mengganggap persahabatan adalah hal yang penting karena beberapa alasan. Selama masa-masa sekolah dasar, teman adalah sahabat untuk bergembira dan melakukan sesuatu. Anakanak yang diterima sebagai sahabat baik cenderung untuk bekerja sama, suka membantu, dan memberi perhatian dan jarang mengganggu atau agresif. Meskipun demikian dengan pendekatan yang dilakukan guru, siswa akhirnya bersedia berkelompok dengan teman lainnya.

Siklus II, siswa sudah mulai dapat beradaptasi dengan tradisi belajar kontruktivisme khususnya dengan pembelajaran kooperatif model STADProblem Solving, siswa belajar secara bebas dalam menyelesaikan tugasnya, artinya melakukan proses aktif membangun konsep baru. Hasil belajar siswa meningkat pada siklus II. Pengalaman yang diberikan pada siswa dapat merubah perilaku siswa (Dahar, 1989; Gunawan, 2008). Meningkatnya pemahaman atau hasil belajar siswa disebabkan pegalaman-pengalaman yang diberikan melalui pembelajaran (Gunawan, 2011). Pada tahap ini siswa belajar menemukan konsep melalui peragaan. Hal ini didukung pendapat Bruner yang menyatakan bahwa berusaha sendiri untuk menemukan pengetahuan akan menghasilkan pengetahuan yang benar-benar bermakna (Dahar, 1989). Ausubel menyatakan bahwa pengetahuan yang dipelajari secara bermakna dapat diingat lebih lama (Dahar, 1989).

\section{SIMPULAN DAN SARAN}

Berdasarkan hasil penelitian disimpulkan penerapan pembelajaran dengan model STADProblem Solving dapat meningkatkan kualitas proses pembelajaran dan hasil belajar matematika. Penerapan pembelajaran Model STAD-Problem Solving dapat menghasilkan desain model pembelajaran yang baik. Mengacu pada hasil penelitian, saran yang diajukan bagi guru mata pelajaran matematika, hendaknya menggunakan strategi pembelajaran kooperatif model STADProblemSolving, dalam pelaksanaan pembelajaran matematika selama situasi dan kondisi sekolah relatif sama dengan kondisi dalam penelitian ini. Bagi peneliti lain ialah mengembangkan penelitian ini, yakni dengan meneliti dampak dari penerapan pembelajaran kooperatif model STAD-Problem 
Solving pada materi bilangan bulat dengan memberi alokasi waktu diskusi kelompok lebih lama dari yang dilaksanakan dalam penelitian ini.

\section{DAFTAR RUJUKAN}

Akbar, S. 2009. Penelitian Tindakan Kelas. Yogyakarta: Cipta Media Aksara.

Billstein, R. 2010. A Problem Solving Approach to Mathematic for Elementary School Teachers.

Cooney, T. J., Davis, E. J., \& Henderson, K. B. 1975. Dynamics of Teaching Secondary School Mathematics. Boston: Houghton Mifflin.

Dahar, R. W. 1988. Teori-teori Belajar. Jakarta: Dedikbud P2LPTK.

Driver, R. 1994. Constructing Scientific knowledge in the classroom. Educational Researcher, 23(7), 5-12.

Gabel, D. 1999. Improving Teaching and Learning through Chemestry Education Research: A Look to the Future. Journal of Chemestry Education, 76(4), 548-554.

Gunawan, I. 2008. Pendidikan Perdamaian. Banjarmasin Pos, hlm. 6.

Gunawan, I. 2011. Merekonstruksi Fitrah Pendidikan. Komunikasi, Majalah Kampus Universitas Negeri Malang, Tahun 33 Nomor 276 September - Oktober 2011, hlm. 32.

Gunawan, I. 2016a. Metode Penelitian Kuantitatif, (Online), (http://fip.um.ac.id/wp-content/ uploads/2015/12/2_Metpen-Kuantitatif.pdf), diakses 2 Desember 2016.

Gunawan, I. 2016b. Model of Educational Leadership in the Implementation of Curriculum 2013. Proceedings The $4^{\text {th }}$ International Conference Language, Society, and Culture in Asian Contexts (LSCAC 2016) on Cultivating and Casting Asian Diversities: Empowering the Asians, 24 s.d. 25 Mei.

Hamalik, O. 2001. Proses Belajar Mengajar. Jakarta: Bumi Aksara.

Hudoyo, H. 1998. Mengajar Belajar Matematika. Jakarta: PPLPTK.

Hudoyo, H. 2001. Pengembangan Kurikulum dan Pembelajaran Matematika. Jurusan Pendidikan Matematika, 12(2), 12-19.
Johnstone, A. H. 2000. Teaching of Physicslogical or Psychological? Physics Education: Research and Practice in Europe, 1(1), 9-15.

Muslimin, I. 2000. Pembelajaran Kooperatif. Surabaya: Universitas Negeri Surabaya.

Orton, A. 2001. Learning Mathematics. Bloomsburry Publishing.

Permendiknas Nomor 22 Tahun 2006 tentang Standar Isi Sekolah Dasar. 2007. Jakarta: Depdiknas

Polya, G. 1973. How to Solve It. Princeton: Princeton University Press.

Sadiman, A. S. 2007. Media Pendidikan. Jakarta: PT Raja Grafindo Persada.

Slavin, R. E. 1994. Education Psycology Theory Into Practice. 4th Ed. Boston: Allyn and Bacon.

Slavin, R. E. 2008. Psikologi Pendidikan Teori dan Praktik. Terjemahan Marianto Samosir. Jakarta: PT Indeks.

Slavin, R. 2010. Cooperative Learning: Teori, Riset dan Praktik. Bandung: Nusa Media.

Solikhati. 2009. Peningkatan Hasil Belajar Matematika melalui Model Pembelajaran Kooperatif Tipe STAD. JPMS Jurnal pendidikan Matematika dan Sains, 14(1), 2531.

Stieff, M., \& Wilensky, V. 2003. Connected Chemistry-Incorporating Interactive Simulations Into The Chemistry Classroom. Journal of Science of Education and Technology, 12(3), 285-302.

Sumarno, A. 2011. Peningkatan Pembelajaran Matematika Berorientasi Open-Ended Problem Solving untuk Meningkatkan Kualitas Proses dalam Pemecahan Masalah pada Siswa SD Kelas V Banyuasri. Jurnal Alternatif, 8(2), 12-17.

Supriyatiningsih, E. 2008. Melalui Penerapan Strategi Belajar Kooperatif Tipe STAD Bagi Siswa Kelas VI SD Negeri 1 Godong Hasil Belajar Matematika Meningkat. Jurnal Widyatama (Jurnal Pemikiran Pendidikan), 5(4), 12-19. 